\title{
Mixed Messages: Resistance and Reappropriation in Rave Culture
}

Brian L. Ott

Department of Speech Communication, 204 Eddy Building, Colorado State University, Fort Collins, CO 80523-1783. Office: (970) 491-7164. Email:Brian.Ott@colostate.edu

Bill D. Herman

Department of Speech Communication, 232 Eddy Building, Colorado State University, Fort Collins, CO 80523-1783. Office: (970) 491-3852. Email: talk@lamar.colostate.edu

This essay concerns the dynamic tension between resistance and reappropriation in the youth subcultural practice of raving. We argue that the transgressive potential of underground rave culture lies primarily in its privileging of communion, which is facilitated an the inters facilitated along the intersecting axes of social space, authorship, the body, and the drug Ecstasy. The commodif consciousness reflected in changing attitudes toward Ecstasy, the relocation of dance culture into clubs, and the redefinition of the DJ as artist and superstar. A concluding section considers the implications of resistance and reappropriation in rave culture for social change and the exercise of power.

Back in the days before America was online, computer geeks who liked techno music began hosting secret rave parties in San Francisco. Revelers followed treasure hunts, whispering passwords to strangers on street corners until a rave emerged in somebody else's warehouse or field. The drug ecstasy was passed around like Tic Tacs, and the music played until the cops showed up. Now, a generation later, Tacs, and the music played until the cops showed up. Now, a generation later,
underground raves have gone pop. Last weekend at 3 Com Park, nearly 29,000 underground raves have gone pop. Last weekend at 3 Com Park, nearly 29,000
peaceful ravers queued up in broad daylight, $\$ 40$ tickets in hand, for the largest, cleanest rave San Francisco has ever seen. "Raves are more like concerts now," said James Olson, a rave promoter with B3 Candy who recently drew 42,000 people to the Long Beach Civic Center. "It's all about money; that breaking into the warehouse stuff is a thing of the past." (May, 2001, p. A1)

BRIAN L. OTT (Ph.D., Pennsylvania State University) is an Assistant Professor in the Department of Speech Communication at Colorado State University. Bill D. Herman (M.A., Colorado State University) is a Lecturer in the same department and a Colorado DJ (DJ Talk). An earlier version of this manuscript was presented as a competitive paper in the Critical and Cultural Studies Division at the 2002 National Communication Association convention in New Orleans, LA. The authors wish to thank Greg Dickinson and the many anonymous reviewers for their helpful comments on previous drafts. 
7 HE TRANSFORMATION of rave culture from underground, and fre1 quently illegal, dance parties organized by electronic music lovers to highly publicized popular concerts sponsored by local radio stations and major music labels was predictable, if not wholly inevitable. After all, part of capitalism's appeal lies in its ideological flexibility-its capacity to embrace transgressive subculture, repackage it, and sell it as the latest stylistic innovation. Though predictable, rave culture's evolution was and continues to be anything but simple and straightforward. It entails a set of complex negotiations surrounding the meanings of artist, authorship, and authenticity. It reflects deeply fought ings of artist, authorship, and authenticity. It reflects deeply fought ism, performance and product, and sharing and spectacle. It evokes criticism from youth who feel that the "true spirit" of raving has been lost and praise from parents who applaud the end of this delinquency. It is, in short, a process that highlights the dynamic tension between resistance and reappropriation, between counterculture and commodification.

Rave culture provides an especially instructive site for exploring this tension on at least two counts. First, in a postmodern consumer culture where identity is increasingly tied to the active consumption of images and styles (Kellner, 1995; van Poecke, 1996), music is among the most central and significant ways that youth articulate style and hence a sense of self (Christenson \& Roberts, 1998; Hebdige, 1981; Shuker, 1994; Thornton, 1996). By studying a musical subcultureparticularly one as socially, politically, and economically influential as raving-we hope to illuminate the varied ways that youth continually (re)negotiate difference in constructing their identities. ${ }^{1}$ Second, an analysis of rave culture allows for a consideration of rhetoric's widely overlooked material dimensions (Blair, 1999, pp. 16-17). Music is not merely a symbolic experience; it is also an embodied experience. Music acts directly upon and is quite literally felt by the body. In the case of rave culture, the rhetorical force of music on the body is shaped by both where (the venue) and how (drug use) the music is experienced. As we demonstrate, the meanings, functions, and politics of rave culture have mutated as the sites of raving and the drugs associated with it have changed. As such, this study stands to deepen our understanding of how the materiality of rhetoric is connected to corporeality and social space.

In exploring these issues, we contend that underground rave locates its transgressive character in the logic of communion. ${ }^{2}$ We argue further that the commercialization of rave culture by the music industry subverts the logic of communion in favor of commodity spectacle through the relocation of dance culture into clubs and the redefinition of the DJ as artist and superstar. Before proceeding with our analysis, however, we review the literature on resistance and youth subculture as a theoretical basis for interpreting the practices and products of raving. We, then, offer a brief overview of the origins of rave culture by situating it within the culture of music more broadly.

Theoretical Impulses: Defining Resistance

Resistance is a notoriously elusive category of analysis, as it raises the question, "resistance to what?" A common, though troublesome, answer to that question is domination because it suggests that resistance and power are independent of and diametrically opposed to one another. If domination was truly carried out in this manner, however, it is difficult to imagine how social change would ever occur. That social structures and relationships do change (if only slowly and subtlyshort of revolution) suggests that the field of power-where meanings are made and contested (Brummett, 1994, p. 4)-entails a neverending negotiation of competing ideologies. This is a point made ardently by de Certeau (1984) and Foucault (1980), who claim that there is no space outside power. Rather, resistance is always already situated within a network of power relationships and thus resistive practices must make creative and adaptive use of the resources of the other (de Certeau, 1984, p. 37).

In keeping with this viewpoint, we define resistance as those symbolic and material practices that challenge, subvert, or suspend the cultural codes, rules, or norms, which through their everyday operation create, sustain, and naturalize the prevailing social structure in a particular space and time. Our aim here is to provide a definition that is both sufficiently broad enough to include a wide range of cultural practices and sufficiently conjunctural enough that such practices be thought of, not as universally resistive, but as "specific to particular times, places and social relationships" (Barker, 2000, p. 342). As we are defining it, then, resistance does not oppose domination from some space outside of power and history. It is, instead, a struggle over meanings that occurs within a "discursive formation" (Foucault, 1972, p. 38). Of interest to us is the precise ways in which the concepts of artist, authorship, and authenticity get negotiated and defined within rave culture. Toward that end, we trace the changes in these concepts across the history of raving. Before proceeding, however, we offer two cautionary notes. Our analysis offers only a snapshot of an ongoing struggle within the culture of music. Like a photograph, our analysis imposes a frame on a process, and thus potentially creates an undue perception of unity and closure. Also, our analysis is not intended to romanticize early rave culture and to demonize its more recent iterations, only to demonstrate how the meanings of certain concepts have been reworked in one genre of music at a particular historical moment.

Roots of Resistance: Origins of Rave

Rave culture is the result of transatlantic musical and cultural cross-pollination, drawing influence from American and European 
music scenes. The rave DJ's style of mixing multiple records originated in the disco era, when dance club DJs using variable-speed turntables began stringing together songs with similar beats in order to keep the dancers moving. Influenced by European electronic musicians-especially the German quartet Kraftwerk-disco artists on both sides of the Atlantic began producing electronic dance music. Built upon thick, synthesized, repetitive beats in $4 / 4$ time, this music became increasingly useful to the mixing DJ. The predictable, electronically timed beats lined up nicely with one another, and DJs could mix together the sound from two records, playing them simultaneously for an extended period of time.

In the late 1970 s and early ' 80 s, electronic dance music became a vital outlet for gay communities in American cities-especially New York and Chicago, where garage and house music originated. Underground dance clubs in these cities filled with Black (and to a lesser extent Latino) gay men, who found themselves oppressed on two counts. Collin (1997) explains:

This contributed to a powerful, pent-up frustration which found its release in the clubs, the only place where they could truly be themselves and play out their desires without fear or inhibition. The explosion of energy, therefore, was enormous; the bonding too. The rhetoric of unity and togetherness which echoed down through club cultures to come was forged in these clubs, under pressure from an oppressive world. (p. 17)

Early DJ heroes Larry Levan and Frankie Knuckles-at the Paradise Garage in New York and the Warehouse in Chicago, respectivelyprovided the soundtracks for ecstatic celebrations that served as a locus of cultural resistance.

Levan and Knuckles were innovative users of technology (employing reel-to-reel tapes to create their own remixes, for instance), and their style of music and the trend of electronic musical innovation soon began to spread. Driving back and forth to Chicago to sell records and visit the former Warehouse, which had reopened as the Music Box, Detroit producers such as Juan Atkins, Derrick May, and Kevin Saunderson established a new type of sound called techno (Brewster and Broughton, 2000, p. 320). Unlike New York's garage and Chicago's house sounds, which often contain and/or closely resemble traditional instruments such as bass guitars and drum kits, techno is alien and futuristic. As Brewster and Broughton explain, "it wants to free itself from the baggage of all the world's previous music and take a few brave steps into the future.... It has rejected representation in favor of abstraction" (p. 320). While garage and house utilize digital instruments such as samplers, synthesizers, and beat boxes, techno is inconceivable without them. Instead of modifying traditional musical sounds with technology, technology becomes the means for creating music.

With a penchant for electronically-derived pop music, Europeans were a ripe audience, and house, garage, and techno quickly caught on in European dance clubs. Thus, American dance music helped fuel the popular, widely attended youth dance scene that was still years away in the States. For many youth, the commercial nature of clubs was unfulfilling, however, and by the late 1980s, youth in London and Manchester began throwing large underground dance parties in fields, warehouses, and airplane hangers. ${ }^{3}$ Within a few years, a recognizable rave culture had crossed the Atlantic, taking up residence in New York, Los Angeles, and San Francisco before spreading to the ski slopes of Colorado and the cow pastures of Wisconsin (Champion, 1997, p. 95). By participating in these renegade alternative-venue events (later shortened to "raves"), dancers were challenging social norms and confirming the belief that, "Dancing is political, stupid" (Brewster \& Broughton, 2000, p. 362).

\section{Underground Raves and the Ecstasy of Communion}

But just what are the "politics" of dancing and of the dancing at raves in particular? In this section, we contend that the transgressive potential of underground raves is captured most fully in the concept of communion. Derived from the Latin communis, which means "common," communion refers to the sharing of common substance, to an "intimate fellowship" in which traditional hierarchies are flattened. At an explicit level, underground rave culture fosters communion through the commonly articulated concept of PLUR. Coined in the early 1990s, PLUR-peace, love, unity, and respect-enunciates a set of moral guidelines and rules for participating in raves (LaGassa, 1996). As we are more interested in the unspoken practices of rave culture, however, our examination focuses specifically on how underground raves facilitate communion along the intersecting axes of social space, authorship, corporeality, and the drug Ecstasy.

\section{Spatial Appropriation and Transformation}

No analysis of power relationships should ignore the importance of social space. After all, the ability to control and manipulate power relationships hinges upon the victory of place over time. A subject with will and power becomes possible as soon as it "postulates a place that can be delimited as its own and serve as the base from which relations with an exteriority composed of targets or threats (customers or competitors ....) can be managed" (de Certeau, 1984, p. 36). The discotheque, for instance, provides the owner with a certain power over the customer, not least of all by constituting discotheque-goers as customers. The owner decides what counts as entertainment, establishes the price of entertainment (admission, liquor, etc.), and creates and enforces the rules of acceptable behavior. In short, the discotheque allows the owner to manage the crowd despite its changing face from night to night. Resistance, then, often involves spatial appropriation. Appropriated spaces are one version of what Foucault (1986) terms 
heterotopias, "which are something like counter-sites, a kind of effectively enacted utopia in which the real sites, all the other real sites that can be found within the culture, are simultaneously represented, contested, and inverted" (p. 24). Since spatial appropriation entails the temporary poaching of place, rather than its ownership, time is privileged over place. These heterotopias, explains Foucault (1986), "are linked ... to time in its most fleeting, transitory, precarious aspect, to time in the mode of the festival. These heterotopias are not oriented toward the eternal, they are rather absolutely temporal" (p. 26).

Foucault cites "fairgrounds, these marvelous empty sites on the outskirts of cities that teem once or twice a year" as an example of such counter-sites. But we contend that cow pastures, old theaters, warehouses, and other large spaces that are seized-often with the aid of a crowbar - to stage underground raves furnish clearer cases of transitory, carnivalesque spaces. Whereas the prevailing social structure typically sanctions the temporary appropriation of space for carnivals and fairs, it rarely did so in the case of early raves. In fact, most underground raves were not scheduled to last for a specified amount of time; rather, they continued-sometimes for several days-until the police arrived and ownership of the place was re-established. The co-optation of space and temporary liberation of it from the social structure, then, was absolutely central to the transgressive character of early rave culture. "A rave," Brewster and Broughton (2000) note, "was an idealized version of clubbing. It wasn't about visiting some purpose-built venue, it was about creating something new; it was about building a city for a night. A club had a place ... but a rave was made of possibilities" (p. 370).

Given the obvious legal issues raised by breaking into buildings or taking over fields, the location of underground raves was, in the early years, kept a secret until a few hours before the party. ${ }^{5}$ At that point, ravers would dial a phone number they had discovered on the Internet ravers would dial a phone number they had discovered on the Internet parking lot or record store where they would get directions to the rave (Hanrahan, 2001, p. E1). The secrecy surrounding the location of underground raves also served to heighten a sense of community by uniting ravers in specialized knowledge and transforming the quest for the location into a ritualistic pilgrimage.

By transforming a physical place into a festive moment, raves generated the possibility for a musical experience that was no longer driven exclusively by the logic of the socio-economic order (Gaillot, 1999 , p. 20). With ownership (and control) displaced for a time, the festive moment of the rave, like carnival, "celebrated temporary liberation from the prevailing truth and form of the established orderation from the prevailing truth and marked the suspension of all hierarchical ranks, privileges, norms and prohibitions" (Bakhtin, 1968, p. 10). This flattening of hierarchy is further reinforced by the organization of social space within raves. Unlike most artistic, especially musical, events in the West, the stage is absent in underground rave culture. "The entire apparatus of the mise-en-spectacle is thereby shaken," observes Gaillot (1999); "Indeed, once there is no longer any privileged space, no more 'spectacular altar,' so to speak, there is also no longer a center toward which looking can be directed and focused" (p. 58). Whereas rock or pop enthusiasts attend concerts, in part, to witness (i.e., behold) a musician or band, ravers attend raves to create and participate in an experience that cannot exist apart from their participation. The point here is not that rave culture is wholly resistive and rock culture wholly complicitous (for such a point would miss Foucault's contribution to resistance), but that underground rave culture resists the prevailing set of cultural codes concerning the organization of space at musical events-codes that construct the artist/audience relationship in particular ways. The carnival metaphor again offers insight, for raves, too, are "not a spectacle seen by the people; they live in it, and everyone participates because its very idea embraces all the people" (Bakhtin, 1968, p. 7) The highly temporal, festive, decentered, and participatory social space of raves is about coming together in a spirit of freedom, equality, and communion. Since discursive space is closely related to social space, the creation of new social spaces and transformation of old ones (as with raves) opens the door for new types of discourse (Stallybrass $\&$ White, 1986, p. 80). It is to those discourses that we now turn.

\section{Deconstructing the Author and Dispersing the Text}

Discourse is typically thought of as an individually authored message addressed to an identifiable audience, in which the author is outside of and precedes the text (Foucault, 1977, p. 115). The prevailing conception of the author is as an autonomous figure, originator of ideas and meanings. It is a conception that society aggressively reinforces and polices through copyright law. The author has also historically been a patriarchal figure who, as Gilbert and Gubar (1979) observe, "is a father, a progenitor, a procreator, an aesthetic patriarch whose pen is an instrument of generative power like his penis" (p. 6) But early rave culture deconstructs the function of the author, problematizes the whole notion of reception and consumption, and fosters a collaborative experience in which all the participants (artists, DJs, dancers) contribute equally to a living text (Gaillot, 1992, pp. 52-3). The capacity of raves to become living texts "experienced only in an activity of production" (Barthes, 1988, p. 157) is closely connected to the unique character of the music and its performance at these events.

The music is mixed by DJs, using record players as samplers, ${ }^{6}$ and for most dancers, the identification of the original artists is both unimportant and nearly impossible. The electronic music performed by DJs, contends Langlois (1992), "is largely devoid of visible 'musicians,' and is almost entirely instrumental in nature, its appeal to today's 
youth does not lie in an empathy with lyrical content nor, to any great extent, individual 'personalities' ... . [and] the vast majority of records seem to be unknown to the dancers at the events" (p. 229). Underground rave culture further decenters the notion of artist (the music industry's version of author), and corresponding culture of commercialism, by extending the music in a perpetually unfinished fashion. Music at raves is mixed without the slightest interruption, even when DJs are changed (Hadley, 1993, p. 59). In fact, the DJ's primary purpose is to ensure that the rhythm is never interrupted and that the bodies of the dancers never stop moving (Mattila, 1999, p. 57). Unlike rock concerts, where artists play identifiable songs in established sets, the music at raves is continuous, fluid (even when mixing the same tracks, DJs mix them differently each time), and unidentifiable. In short, it calls into question the idea of artist as original and autonomous author and the idea of artwork as finished form. Raves are an ensemble performance involving the interaction of music, DJ, and ravers, in which no element is more or less important than the rest. ${ }^{7}$ In fact, in early rave culture, Gaillot (1999) notes that, "[DJs did] not consider themselves artists, even less stars . . . . They refuse[d] 'aura,' as attested by the widespread anonymousness in the movement .... DJs [were] not even announced or introduced, nor [were] they applauded for their performance; most of the time we [did] not even see them" (p. 52).

Rock concerts, with their superstar artists and individual songs or artworks, ${ }^{8}$ are structured to encourage a particular mode of participation in which the audience consumes the artistic product. Underground raves, by contrast, are living art whose subversive force is constituted precisely in the disruption of the categories of artist and audience. Though resistance is certainly not absent from rock concerts, it is typically not enacted in a manner that challenges the artist/audience dichotomy. One of the relatively unique transgressive characteristics of rave culture, therefore, is the implosion of the artist/audience dichotomy and the shift from the "music one listens to" to the "music one plays." Barthes (1988) describes the difference in this manner:

The music one plays comes from an activity that is very little auditory .... It is the music which you or I can play, alone or among friends, with no other audience than its participants; a muscular music in which the part taken by the sense of hearing is one only of ratification, as though the body were hearing-and not 'the soul' .... The body controls, conducts, co-ordinates, having itself to transcribe what it reads, making sound and meaning, the body as inscriber and not just transmitter, simple receiver. (p. 149)

In light of the body's importance to the experience of music at raves, along with the recognition that "body-images 'speak' social relations and values with particular force" (Stallybrass \& White, 1986, p. 10), it is worth examining the ideological function of the body in rave culture more closely.

\section{Dancing Bodies and the Loss of Self}

Electronic music is first and foremost dance music. ${ }^{9}$ The loud, pulsating bass and repetitive beats reverberate through the whole body, ensuring that dancers move in unison with the music and with each other. The mere centrality of the body in rave culture is itself transgressive. Binary concepts such as mind/body always entail hierarchy, and throughout much of Western philosophy and religion, the body has been coded as untamed and impure and subordinated to the intellectual and spiritual activities of the mind and soul. ${ }^{10}$ But rave culture inverts this hierarchy and celebrates Dionysian principles over Apollonian ones. Whereas Apollonian logic signifies order, self-control, balance, and the mind, the Greek god Dionysus denotes irrationality, ecstasy, inebriation, loss of individual identity, and the body (Grosz, 1994, p. 130). Bodies can, of course, be coded in a variety of ways, and the image of the raving body suggests a second level of transgressiveness. Unlike the classical body of Ancient Greece, symbolizing cleanliness and purity, and separated from its surroundings (or elevated above them by a pedestal), the raving body shares more in common with the grotesque body of carnival, "which was usually multiple, teeming, always already part of a throng" (Stallybrass \& White, 1986, p. 21). At raves, bodies intermingle, often intimately and indiscriminately through touch and dance. Animated by the rhythm of the music, dancers move together in a trance-like state. ${ }^{11}$ When rave participants enter "trance-dance," the very notion of individual being is effaced and communion through dancing is achieved. "In his [sic] Dionysiac state," explain Silk and Stern (1981), "a man feels that all barriers between himself and others are broken in favor of a rediscovered universal harmony .... [and] all things are as one. There is, in fact, no place for any distinctions, for anything that sets one thing off against any other thing: limits, forms, conventions, individuals" (p. 64).

The loss of self characterized by the being-together of bodies in a state of ecstasy is referred to as jouissance by Barthes (1992), and carries great ideological significance. The body is a key site of social control and therefore among the most disciplined sites within any social structure. Social control relies, to some extent, on self-control (the body acting within prevailing norms and conventions), and selfcontrol implies individually constituted subjects. The temporary erasure of individuality furnished by trance, then, is the loss of selfcontrol, or more accurately the pleasure of the body out of control. It is also a loss of social control-an "evasion of ideology" (Fiske, 1989, pp. 51-2). Jouissance describes a way of experiencing music, and while other types of music can be experienced in this way, context often functions to inhibit it. At an opera or rock concert, for instance, attendees are constituted by the venue, whether symphony hall or football stadium, as an audience. The presence of a stage and the direction of attention to that stage affirm order (and social control), and subse- 
quently the disciplined body applauds or cheers at the end of each number. At raves, however, there is no artist or audience, only the decentered and dirty body. Dirty does not refer here to actual dirt, but to disorder, as in the mixing of categories, the deconstruction of artist and audience, the dissolving of self into the ecstatic body (Fiske, 1989, p. 90; Melechi, 1993, p. 35; Stallybrass \& White, 1986, p. 23). In underground rave culture, Ecstasy is more than just a metaphor for the body, though; it is also the preferred cultural artifact.

\section{Ecstasy as Drug and Consciousness}

Every cultural group adopts or produces artifacts through which it articulates its overall values and structure. The concept of homology refers to a close fit between an artifact and the lived culture that surrounds it (Barker, 2000, p. 324; Hebdige, 1981). Homological analysis, then, explains Willis (1978):

[I]s concerned with how far, in their structure and content, particular items paralle and reflect the structure, style, typical concerns, attitudes and feelings of the social group. Where homologies are found they are actually best understood in terms of structure. It is the continuous play between the group and a particular item which produces specific styles, meaning, contents and forms of consciousness. (p. 191)

We contend that the dominant artifact of rave culture, and likely the most homologous as well, is the drug Ecstasy-or E as it is frequently called within the rave scene. As such, an analysis of this drug and its relation to underground rave culture serves to highlight the "focal concerns, activities, group structure and collective self-image of the subculture" (Hebdige, 1981, p. 114). In an attempt to develop an appetite suppressant, the German company Merck first synthesized Ecstasy or MDMA (methylenedioxymethamphetamine) just prior to World War I. MDMA, which stimulates the brain to produce serotonin, produces both physio- and psychological side effects that include boosting one's energy, intensifying and enhancing the senses, and fostering a sense of uninhibited conviviality, empathy, and insight (Richburg, 2001, p. A16).

MDMA is particularly well suited to raving for two reasons. First, the drug, according to Reynolds (1998), "[has] a uniquely synergistic/ synesthetic interaction with music, especially uptempo, repetitive, electronic dance music.... [which] sounds better on E-crisper and more distinct, but also engulfing in its immediacy" (pp. 83, 84). Users of $\mathrm{E}$ report that the drug makes all sensations more vivid and that dancing on $\mathrm{E}$ feels like being inside the music. Second, of all the drugs associated with youth culture, MDMA is by all accounts the most social. "It's rarely used by a solitary individual," Reynolds (1998) explains, "because the [intense] feelings [of empathy] it unleashes would have nowhere to go .... Rave theorists talk of tribal consciousness, 'morphic resonance,' an empathy that shades into the tele- pathic.... When large numbers of people took Ecstasy, the drug catalyzed a strange wondrous atmosphere of collective intimacy, an electric sense of connection between complete strangers" (pp. 85, 83; Saunders, 1996, p. 35). Given the feelings of oneness that accompany the drug, the practice of taking $E$ has itself become a communal ritual not unlike the Christian practice of taking communion. In the early years of rave culture, $\mathrm{E}$ was widely available and taken collectively by partygoers, who would engage in a wide and creative array of touching, massaging behaviors.

But the characteristic of $\mathrm{E}$ that is perhaps most unique and homologous with underground rave culture is its dephallicizing effect on the male body. If rave culture truly flattens hierarchy, promoting oneness, a communion without borders, boundaries, and differences, then it must somehow disrupt the entire disciplinary apparatus of 'sexuality' that serves patriarchal and heteronormative social relationships (Fiske, 1989, pp. 94-95). Though $\mathrm{E}$ intensifies the pleasure of touching and hugging, it largely empties sexual intimacy of its aggressive, masculine content. "E may be the 'love drug'," Reynolds (1997) writes, "but this refers more to agape than eros, cuddles rather than copulation ... $\mathrm{E}$ is notorious for making erection difficult and male orgasm virtually impossible" (p. 88). Not surprisingly, women at raves report feeling much safer than in more traditional dance venues (Saunders, 1996, pp. 42-5). In addition to having an anti-libidinal effect on its users, MDMA helps efface gendered sexual relations. Since Ecstasy enhances feelings of collective love rather than targeted lust, the majority of users do not discriminate by gender, sex, or sexuality in their intimacy with others. In contrast to club culture, which privileges consumption, sexual conquest, and being an audience, underground rave culture privileges communion, the ecstasy of jouissance, and oneness with the music and the dancers-if only for a night.

\section{Commercial Raves and the Rise of Commodity Spectacle}

With tens of thousands of youth gathering in hundreds of cities each weekend to dance, the music industry simply could not ignore the potential profits represented by rave culture. Thus, throughout the 1990 s, rave's dance culture was gradually reappropriated and largely relocated into clubs and discotheques-the spaces intended for traditional spectacles. ${ }^{12}$ The transformation of rave culture did not happen quickly or easily, however, and indeed, its success depended upon a fundamental shift in the consciousness of the participants from communion to commodity spectacle. At the heart of this transformation, we contend, was a media public relations war on underground rave culture and in particular, the drug Ecstasy, and the redefinition and promotion of the DJ as artist and superstar. 


\section{Ecstasy Comes Under Attack}

Since rave culture in the UK predates that in the US by about four years, it first came under attack there. The British press featured "regular stories on this corrupting new youth culture" and its "sex-anddrugs orgies" (Champion, 1997, p. 104). By 1993, "stories of people throwing up, then picking the half-digested pills out of the puke and gobbling them down again [and] rumors of kids using syringes to shoot speed in the toilets" (Reynolds, 1998, p. 209) were circulating widely. Anti-rave sentiment grew even stronger in the UK as news of a rash of Ecstasy related deaths spread. What was not widely reported was that a vast majority of these deaths were not caused by Eestasy, but by a rise in "cocktail" pills sold by profiteering drug dealers who cut or replaced MDMA with cheaper, more dangerous drugs designed to resemble the effects of Ecstasy. Nevertheless, public sentiment against raves had reached a fevered pitch, and in 1994, British parliament approved the Criminal Justice Act, which outlawed large-scale unlicensed dance events. Seeking alternative outlets, Brewster and Broughton (1999) explain, "people flooded into the clubs. They swapped muddy fields for the carpets and chrome of the local Cinderella's and carried on partying. The underground scene was legalized (and largely sanitized), money was made and the whole thing was a grand victory for consumerism" (p. 395).

In the United States, which until recently had no law comparable to the Criminal Justice Act, rave culture progressed along a somewhat different path, continuing in outdoor venues, though in a more commercialized form, even as it surfaced in clubs. Shortly after the introduction of rave culture in the US, music promoters began to sponsor spectacular outdoor raves, which attracted youth with large, powerful sound systems, laser-light shows, mass marketed DJs, and funfair rides such as Moon Bounces. Advertised by local radio stations, "super" raves were drawing anywhere from 2,000 to 20,000 dancers for $\$ 30-60$ a ticket. But as in the UK, the growing popularity of raves brought the attention of the media, who again focused on the "scandalous" drug component of the culture, and ensured the scorn of the public. "Drug enforcement officials, lawmakers and health care experts in the United States are sounding a nationwide alarm about Ecstasy," reports Richburg (2001), "calling it the fastest-growing drug in the illegal marketplace" (p. A16). Subsequently, the police began infiltrating raves and cracking down on drug use. At a daylong rave sponsored by Vinyl Lab Productions at the Ann Arundel County Fair Grounds in Maryland, 47 people were arrested on drug charges (Garland, 2001, p. 1B), and at Milwaukee's "Grave Rave," all 950 partygoers were arrested (Champion, 1997, p. 104). Outdoor raves continued, but in a new form as the drug Ecstasy became less and less common.
In the US, rave enthusiasts were not forced into clubs so much as they went willingly. The growing commercialization of outdoor raves contributed to the rise of superstar DJs, who were now being followed from venue to venue by loyal fans. Moreover, club raves were not that much different than the commercial outdoor variety, especially at first, since many rave promoters turned a blind eye to drug use in these clubs. Some promoters signaled the drug's presence and acceptability at events through not so subtly coded messages on flyers-a publicity trick mimicked by the Denver radio station KTCL, who feature a nightly show titled "E-lectronica at E-leven" and recently sponsored a rave/concert titled "Weekend of E." Other promoters, knowing that Ecstasy results in dehydration, even tried to profit off it indirectly by charging exorbitant fees for bottled water (Goldstein, 2001, p. C3). As a result of continued Ecstasy use, some elements of the communal spirit that had dominated underground raving survived the initial transition to clubs. But all of that was about to change.

Ecstasy, whose effect is severely undercut by alcohol consumption, was significantly hampering the alcohol trade. In fact, a 1995 survey of college-aged students found that while $\mathrm{E}$ use had doubled in recent years, alcohol use had halved (Saunders, 1996, p. 23). Though underground raves are predominantly alcohol-free events, dance clubs depend on alcohol sales for their livelihood. So as long as Ecstasy was the drug of choice, commercialized raving was in jeopardy.

Over the course of the next few years, attitudes of club owners and rave promoters toward $\mathrm{E}$ would change drastically. Many club owners, suffering from lagging alcohol sales, voluntarily began to police drug use, especially Ecstasy, in their clubs. Security guards posted at the doors of clubs would ask patrons to empty their pockets, confiscating glow sticks, pacifiers, Vicks Vapor Rub, and other E-related paraphernalia. ${ }^{13}$ But rave promoters, who make their money off ticket sales rather than alcohol, were less compelled than owners were to crack down on illegal drug use-that is, until the highly publicized and unprecedented case at the State Palace Theater in New Orleans. In this instance, prosecutors went after "three local rave promoters ... [who] profited off holding ecstasy-soaked parties," filing federal drug charges that potentially carried up to 20 -year sentences (Filosa, May 2001, p. 1). What was remarkable about this case is that there was no evidence the promoters were selling drugs. Indeed, it marked "the first time promoters and management have been brought up on federal charges for patrons' private drug use" (Chonin, 2001, p. 52). To avoid jail time, the three men pled guilty, agreeing to pay a $\$ 100,000$ fine and ban rave-related items from all future events (Filosa, June 2001 , p. 1). Prior to settlement, the defendants in that case faced prosecution under the 1986 "crack house" law-a law designed with the prosecution of private residents, not commercial promoters and business owners, in mind. 
A year later, Ecstasy use at raves came under further attack when Senator Joseph Biden introduced the "Reducing Americans' Vulnerability to Ecstasy Act of 2002" or "RAVE Act" into Congress-a bill designed to make it significantly easier to prosecute cases like the one in New Orleans. After this bill failed to pass, Biden renamed it "The Illicit Drug Anti-Proliferation Act" and attached it as a rider to the popular Amber Alert legislation-an unrelated bill designed to help locate missing children. This bill passed, as amended, in April 2003 (Boucher, 2003, p. 3) on its way to President Bush's eager signature. The new law readily exposes rave promoters, events coordinators, and property owners to federal prosecution for drug use on their premises or at their events. As the ACLU (2003) explains, "no matter how much security is put in place, owners could be held responsible for the actions of just one customer and would therefore be much less likely to allow raves to take place in their clubs or concert halls" (para. 2). In short, the State Palace Theater case is just the beginning of an official federal crackdown on rave culture. In combination with the economic pressure of selling liquor, the ever-increasing legal pressure has helped displace Ecstasy as the drug of choice in clubs, and rave culture's communal character has steadily given way to a more meat-market mentality.

\section{The Changing Face and Function of the DJ}

In its early incarnations, rave culture deconstructed the notions of author and work, replacing them with a living text that resulted from the collaborative performance of DJs and ravers and existed only in the moment of their interaction with the music. The challenge posed to the music industry by the idea of "author as fiction" is that there is nothing to market. For many years, DJs were not considered artists because public perception was that anybody with the right equipment could DJ. "[T] he elevation of all consumers to potential creators," explains Sanjek (1992), "denies the composer or musician an aura of autonomy and authenticity ... and the product[s] no longer possess the meanings once assigned them" (p. 609). If the DJ was going to become a marketable commodity, s/he first had to be redefined as someone who does more than simply play other people's records. ${ }^{14}$ Thus, discourse in the music industry began to shift and DJs came to be known as "musicians, virtuosos who elevate turntables far beyond mere mechanisms for playing back vinyl LPs" (Reighley, 2000, p. 11). DJs are now said to possess unique technical and artistic skills such as beat matching (keeping two songs at the same tempo), mixing (laying one track over another, often in segue from one to the other), juggling (using two copies of the same record to create a new and different beat), cutting and re-introducing tracks (turning the sound off and on in time), and scratching (dragging a record forward and backward). The more artistic and expressive aspects of DJing reside in the ability to create moods and to convey a sense of flow through the selection, juxtaposition, and blending of tracks. In short, the creative recombination of pre-existing material is now seen as a viable artistic practice in a postmodern landscape (Poschardt, 1998, p. 16).

As the DJ was transformed from someone who operates a turntable into an independent artist, the DJ also became a superstar (Mattila, 1999, p. 56). Inside the club, the DJ is no longer decentered or anonymous. The majority of clubs feature elaborate DJ booths, generally at either the head of the dance floor or right in the center. In repositioning the DJ, the grotesque body of the crowd that had characterized underground raves is displaced by the classical figure of the artist. The symbolic significance of such a shift is well captured in Stallybrass and White's (1986) analysis of the classical statue; "the classical statue is the radiant center of a transcendent individualism, 'put on a pedestal', raised above the viewer and the commonality and anticipating passive admiration from below. We gaze up at the figure and wonder. We are placed by it as spectators" (p. 21). The construction and celebration of the DJ as artist is further reinforced when DJs are changed. Rather than mixing her/his first tune into the previous DJ's song, as was the standard practice in underground raving, a well known DJ might cut the power and allow the previous record to grind noisily to a halt; the break in music announces the new DJ who is often greeted by enthusiastic cheers (Brewster \& Broughton, 2000, p. 384). In dance clubs today, fans clamor around DJ booths, watching every move, for DJs have "replaced supermodels as the new 'hot' celebrities" (Reighley, 2000 , p. 203). In fact, as DJs have gained prominence in the media and record industry, they have become some of the most highly paid people in the entertainment world (Haslam, 1997, p. 150).

But no one has profited more from the growing celebrity of the DJ than the music and record industry. Popular, trade, and industry magazines hype DJs as pop idols. They are interviewed on radio and television, and the right lineup of DJs on an event flyer guarantees music and event ticket sales. Today, fans frequently describe their musical tastes by referencing particular DJs, rather than particular genres of records (Brewster \& Broughton, 2000, p. 386). By the mid1990 s, the legal DJ mix was born, and CDs featuring tracks of other artists mixed by popular DJs were selling in clubs and record stores under the DJ's name (Reynolds, 1998, p. 276). Commodification of the DJ and her/his music has been extended to include her/his lifestyle as well. Record stores feature DJ trading cards, bookstores sell DJ biographies, and shopping mall boutiques offer DJ bags. "Embossed with record company label logos ... [and] 'originally designed for DJs to jockey their twelve inch vinyls from club to club', Haslam (1997) reports, "these tools of the DJ trade are selling at fifty dollars a bag ... 'as a new-school urban briefcase' " (pp. 150-1). The cult of the DJ has transformed rave culture into commodity spectacle. 
Club raving is wildly popular today, but it bears little resemblance to the underground raves of the early 1990s. In contemporary rave culture, the DJ is constructed as an artist, a pop icon to be adored and emulated, and a hyper-masculine patriarch who directs and controls the bodies of the dancers. S/he is author-sovereign God of her/his characters, who have been transformed by her/his aura from participants into patrons. Hence, many of the hierarchies that are flattened by underground rave culture are reanimated in its reappropriation by the music industry. The commercialization of rave culture finds the heterotopia of the invaded field replaced by the official space of the club (or sanctioned use of the fairground), the performance of the ravers replaced by the artistic product of the DJ, the freeing pleasure of jouissance replaced by the disciplining pleasure of accepting readymade meanings, and the logic of communion replaced by the logic of commodity spectacle.

\section{Resistance, Reappropriation, and Back Again}

Our analysis of resistance and reappropriation in rave culture is marked by some important limitations. Chief among these limitations is the way our chronological organization and focus on space, authorship, corporeality, and communion constrains the analysis. Although organizing the essay historically allowed us to carefully trace the reworking of these particular concepts in rave culture over time, it also potentially contributes to the misperception that underground rave culture is inherently resistive to and commercial rave culture fully complicitous with hegemonic capitalism. This is an unfortunate consequence of our approach that warrants further comment. Although the practices of underground rave culture suggest some exciting and even potentially liberating possibilities, one can never escape discipline and control altogether, as some disciplining structure is always at work (Foucault, 1980). Regardless of how decentered and disorderly underground rave culture may outwardly appear, it nevertheless obeys certain "rules of disorder" through the construction of cultural norms (Featherstone, 1991, p. 20). We did not, for instance, write about the ways that social hierarchies often emerge among categories of ravers at underground raves, even as those events challenge the hierarchy between artist and audience. Likewise, we did not attend to the ways that ravers at commercial venues enact their own modes of tactical resistance-to the ways that they subvert the capitalist structure, for instance, by making and circulating bootlegged mixes. As such, the current contours of club raving should not be regarded as an end state, as youth have already begun to poach it, transform it, and invent their own pleasures from it (Brewster \& Broughton, 2000, pp. 407-8).

Despite these limitations, an analysis of rave culture does offer some insights into resistance theory and the structure and function of the music industry. This study suggests that resistance is more profitably conceptualized as a process than as a universal outcome. To simply conclude that subcultural practices such as raving are transgressive neglects the ways that the prevailing social structure negotiates subversive symbolic practices and adapts them to serve existing social relationships. Too often, resistance is blindly assumed to promote deep structural change. The liberatory potential of resistance, however, lies not in its capacity to alter the prevailing social structure permanently, but in the capacity of cultural consumers to make do-to use the resources of the dominant economic order to invent their own meanings and pleasures (de Certeau, 1984, p. xiii).

Public attitudes toward Ecstasy indicate another important finding concerning the capacity of discourse to naturalize an arbitrary social structure. Since the US Drug Enforcement Administration classifies Ecstasy in its most dangerous category, Schedule 1, public opinion against the drug was mobilized with relative ease. However, MDMA, which the DEA notes, "produces profoundly positive feelings, empathy for others, elimination of anxiety, and extreme relaxation" (Drug, n.d.), "was not even illegal until the $1980 \mathrm{~s}$, when it was discovered that it was being used at the rave party scene" (Richburg, 2001, p. A16). Alcohol, which often promotes increased aggressiveness and has been linked closely to violent crimes such as sexual assault (Abbey, 1991; Frintner \& Rubinson, 1993; Koss \& Gaines, 1993; Muehlenhard \& Linton, 1987), is, on the other hand, not an illicit drug. ${ }^{15}$ Our intent here is not to advocate Ecstasy, which presents its own dangers, ${ }^{16}$ but to illustrate how discourse can make one drug appear deviant and another normal-not really a drug at all. It would be profitable to analyze further the apparent homology between commercialized dance culture and alcohol.

Finally, it is worth highlighting that the ability to influence the meaning of authorship is what allows for the commodification of dance music by the record industry. "It is not simply that the performer becomes the hook through which musical performances are given distinctiveness and marketed," explains Straw (1999), "Over the long term, the continuity of performer careers is seen as a way of bringing order to the musical marketplace by introducing a particular kind of predictability" (p. 203). Dance music, from disco to electronica, has always posed a challenge to this predictability. Since the distinctiveness of an original performance deteriorates through its being sampled and mixed into an uninterrupted musical sequence of tracks, it becomes virtually impossible to identify the performer's style. What happens in commercial rave culture is that the site of authorship shifts from the original performer to the DJ, where style is redefined as creative recombination. The specific manner in which each DJ selects and mixes tracks is now the marker of predictability and the guarantee that the musical landscape has order. This order is important not primarily to the DJ, but to the promoters and record labels who would 
package it for profit. "The ideology of creation, which makes the author the first and last source of the value of his work," Bourdieu (1993) argues, "conceals the fact that the cultural businessman [sic] (art dealer, publisher, etc.) is at one and the same time the person who exploits the labour of the 'creator' by ... putting it on the market, by exhibiting, publishing or staging it" (p. 77). Without the "cultural businessperson," the DJ's music is simply a natural resource that may be turned by ravers into ecstatic moments.

As with all cultural phenomena, the future of raving is uncertain. Where it goes and what it becomes next will be a product of how, on the one hand, music lovers invent their own meanings and pleasures from existing structures and resources and, on the other hand, how the music industry and major music promoters respond to and reappropriate subcultural practices and styles. The only thing that is certain in rave culture is that symbolic and material battles over the concepts of artist, authorship, and authenticity will continue to be fought as music lovers strive to make do and music promoters strive to make profit.

\section{Notes}

${ }^{1}$ As Morley and Robins (1989) explain, "identity must be defined, not by its positive content, but always by its relation to, and differentiation from, other positive content, but always by its relation to, and differentiation from, other
[identities)" (p. 10); thus, "difference is constitutive of identity" (1995, p. 45). We [identities]" (p. 10); thus, "difference is constitutive of identity" (1995, p. 45). We
selected resistance as our primary theoretical framework because, as rave emerged, selected resistance as our primary theoretical framework because, as

difference was defined largely in contrast to mainstream music culture.
2It seems worth briefly reflecting on the authorial "we" at this point. One author is a media critic whose primary scholarly interests lie in theories of the everyday. The other author is an established Colorado DJ, who has been involved in rave culture as a participant and promoter for over five years now. In combining these two sets of experiences (and voices), our aim has been to offer a reading of rave culture that is well grounded in both theory and practice. Thus, while the essay may appear to have a single unified voice, it is actually a blending of voices not unlike the mixing of music that characterizes raves.

${ }^{3}$ This is not to say that raving absolutely, indisputably began here. Given its shady legal standing, raving is a notoriously difficult practice to nail down. shady legal standing, raving is a now Nonetheless, historians of music frequently cite these two cities as a particularly important nexus in which essential ele to coalesce. It was here especially that the culture of Ecstasy, imported from the island of Ibiza, off the coast of Spain, would come to be closely associated with raves (Sicko, 1999, p. 114).

We do not mean to suggest that early or underground rave culture is utterly transgressive and recent, more commercial rave culture is not. Rather, we are attempting to show how spatial appropriation was a vital part of rave culture's transgressive character in the early years. Resistance continues to occur in commercial rave culture, but is articulated in different ways.

${ }^{5}$ As raves grew in popularity and hence visibility, promoters continually had to invent new methods of "safely" getting the word out about a rave. According to Brewster and Broughton (2000), "The promoters quickly realized the value of new technology like mobile phones and reprogrammable telephone message lines to keep the address secret unti the last minute. Incredible scams were pulled off to secure sites and to deflect police interest" (p. 372).

${ }^{6}$ Unlike radio DJs, rave DJs do not let tracks play, as songs, from beginning to end. Instead, they use their turntables like samplers, snatching threads of different tracks to weave into a larger musical tapestry. In combination with the volume and equalizer adjustments on the mixer, the variable-speed turntable becomes a sampler. The DJ can choose one part of one track-such as a synthesizer riff-to isolate and add that part to an and the most basic out of samples from records. In this way, the turntable is transformed musical text out of samples from records. In this way, the turntable
from a tool for playing records into a tool for sampling from records.

7"What authenticates.

7"What authenticates ... dance cultures," according to Thornton (1996), "is the buzz or energy which results from the interaction of records, DJ and crowd. 'Liveness' is displaced from the stage to the dancefloor, from the worship of the [rock] performer to a veneration of 'atmosphere' or 'vibe'. The DJ and dancers share the spotlight as de facto performers" (p. 29).

With the word "artworks," we are trying to highlight the difference between music that is consumed by audiences and music that is performed by audiences. In "From Work to Text," Barthes (1988) argues that audiences can use or approach discourse in one of two modes: as works or Texts. Perhaps the greatest difference between these two modes is where they locate the activity of writing. Works respect the sovereignty of the Author-God (the individual artist) and privilege consumption (p. 161). They close down writing (textuality) by imposing limits on reading and (p. 161). They close down writing (textuality) by imposing limits on reading and creating the appearance of a finis work, begins with the "removal of the Author" (Barthes, 1988, p. 145). It
conceptualizes discourse as "a multi-dimensional space in which a variety of writings, none of them original, blend and clash[,] ... a tissue of quotations," and it locates the reader as "the space on which all the quotations that make up a writing are inscribed without any of them being lost" (Barthes, 1988, pp. 146; 148). Thus, "[t]he text is opened out and set going-produced-by the reader in an act of collaboration, not consumption" (Leitch, 1983, p. 107). So, whereas concertgoers typically consume works, ravers produce Texts.

9Thornton (1996) argues that, "The constant pulse of the bass blocks thoughts, affects emotions and enters the body. Like a drug, rhythms can lull one into another state. With rave culture this potentiality was ritualized as the 'trance dance' by dancers actively celting an altered state of consciousness through movement to the music ${ }^{n}$ (p. 60).

${ }^{10}$ The Christian church," explains Fiske (1989), "has traditionally defined the body as the terrain of the devil, as a threat to the purity and control of the soul, and has conceptualized the relationship between the two as one of hostility" (p. 90). See also Grosz (1994, pp. 1-10) and Zita (1998, pp. 202-4).

${ }^{11}$ According to Melechi (1993), "trance-dance moves the body beyond the spectacle of the 'pose' and the sexuality ('romance') of the look, into a 'cyber-space' of musical sound, where one attempts to implode (get into (the sound]) and disappear.... the body is neither the subject of self expression nor the object of the gaze" (pp. 33-4). For a related discussion, see Canetti (1963; pp. 29-34): "In the rhythmic crowd, density and equality coincide from the beginning. Everything here depends on movement.... In the end, there appears to be a single creature dancing a creature heads and a hundred legs and and with the same purpose. When the excitement is at its feel as one" (pp. 30, 32)

${ }^{12}$ As raves have moved into clubs, the "logic" that animates them has become-at least in a sociological sense-more like that of fairs and amusement parks. In postmodern America, "fun fairs and theme parks such as Disney," according to Featherstone (1991), "provide enclaved environments for the controlled de-control of the emotions, where adults are given permission to behave like children again" (p. 80; see also pp. 24-5). Similarly, club raving allows persons to "display a calculating hedonism" (p. 59)-one that, while privileging informality (e.g., relaxed standards of dress and behavior, as well as the exploration of previously forbidden pleasures and emotions), still depends upon greater self-control (p. 45). 
${ }^{13}$ Ecstasy users frequently chew gum or use pacifiers to prevent grinding their teeth-a common side effect of Ecstasy use (Krashinsky, 2001, p. 5B; Richburg, 2001, p. A16). E-users also commonly smear Vicks Vapor Rub on their faces to intensify the roll (i.e., the Ecstasy high).

14Though "DJ culture is distinctly masculine" (Reynolds, 1998, p. 274) and "98\% of DJs [are male]" (Brewster \& Broughton, 2000, p. x), we have chosen to refer to DJs in the gender neutral.

${ }^{15}$ According to the National Institute on Alcohol Abuse and Alcoholism, at least 25 percent of American women have experienced sexual assault. Of those assaults roughly half involved alcohol consumption by the perpetrator, victim, or both. Alcoho contributes to sexual assault by compounding existing risk factors (Abbey et al., 2001).

${ }^{16}$ Recent research suggests that prolonged Ecstasy use may significantly impair short-term habitual memory, long-term episodic memory, and internally cued memory (Derbyshire \& Hall, 2001, p. 4)

\section{REFERENCES}

Abbey, A. (1991). Acquaintance rape and alcohol consumption on college campuses: How are they linked? Journal of American College Health, 39, 165-169.

Abbey, A., Zawacki, T., Buck, P., Clinton, A., \& McAuslan, P. (2001). Alcoho and sexual assault. Retrieved October 03,2002 , from National Institute on Alcohol Abuse and Alcoholism. Access: http://www.niaaa.nih.gov/publications/ arh25-1/43-51.htm

ACLU. (2003). Congress ties anti-rave bill to popular legislation. Retrieved April 07, 2003, from http://www.aclu.org/DrugPolicy/DrugPolicy.cfm?ID $=12280 \& \mathrm{c}=185$

Bakhtin, M. M. (1968), Rabelais and his world (H. Iswolsky, Trans.). Cambridge, MA MIT Press. (Original work published 1965)

Barker, C. (2000). Cultural studies: Theory and practice. Thousand Oaks, CA: Sage Publications.

Barthes, R. (1992). The pleasure of the text (R. Miller, Trans.). New York: Noonday Press. (Original work published 1973)

Barthes, R. (1988). Image, music, text (S. Heath, Trans.). New York: Noonday Press. (Original work published 1977)

Blair, C. (1999). Contemporary U.S. memorial sites as exemplars of rhetoric's materiality. In J. Selzer \& S. Crowley (eds.), Rhetorical bodies (pp. 16-57) Madison, WI: University of Wisconsin Press.

Boucher, G. (2003, April 15). Drug law takes aim at raves. Los Angeles Times, Pt.5, p.

Bourdieu, P. (1993). The production of belief: Contribution to an economy of symbolic goods (R. Nice, Trans.). In R. Johnson (Ed.), The field of cultural production: Essays on art and literature (pp. 74-111). Columbia, MD: Columbia University. Essays on art and literature (pp.
(Original work published 1977 )

Brewster, B., \& Broughton, F. (2000). Last night a dj saved my life: the history of the disc jockey. New York: Grove Press.

Brummett, B. (1994). Rhetoric in popular culture. New York: St. Martin's Press.

Canetti, E. (1963). Crowds and power. New York: The Viking Press.

Champion, S. (1997). Fear and loathing in Wisconsin. In S. Redhead (Ed.), The clubcultures reader: Readings in popular culture studies (pp. 94-105). Malden, MA: Blackwell Publishers.

Chonin, N. (2001, April 8). Save the rave. The San Francisco Chronicle, p. 52.

Christenson, P., \& Roberts, D. (1998). It's not only rock \& roll: Popular music in the lives of adolescents. Cresskill, NJ: Hampton.

Collin, M. (1997). Altered state: the story of ecstasy culture and Acid House. London Serpent's Tail.

de Certeau, M. (1984). The practice of everyday life. Berkeley, CA: University of California Press.
Derbyshire, D., \& Hall, C. (2001, March 29). Ecstasy users 'are damaging their brains'. The Daily Telegraph (London), p. 4.

Drug Enforcement Agency (n.d.). MDMA (Ecstasy). Retrieved January 12, 2002, from http://www.usdoj.gov/dea/concern/mdma/mdma.htm

Featherstone (1991). Consumer culture and postmodernism. Newbury Park: Sage

Filosa, G. (2001, June 14). Sponsor's guilty plea brings rave new world. The TimesPicayune, p. 1.

Filosa, G. (2001, May 29). Weekend rave shakes, but more self-consciously. The Times-Picayune, p. 1.

Fiske, J. (1989). Understanding popular culture. Boston: Unwin Hyman.

Foucault, M. (1972). The archeaology of knowledge and the discourse on language (A. M. Sheridan Smith, Trans.). New York: Pantheon Books. (Original work published 1969)

Foucault, M. (1977). What is an author? (D. Bouchard \& S. Simon, Trans.). In D. Bouchard (Ed.), Language, counter-memory, practice: Selected essays and interviews (pp. 113-138). Ithaca, NY: Cornell University Press.

Foucault, M. (1980). Power/knowledge: Selected interviews and other writings 1972-1977 (C. Gordon, L. Marshall, J. Mepham \& K. Soper, Trans.). New York: Pantheon Books.

Foucault, M. (1986). Of other spaces. Diacritics, 16(1), 22-27.

Frintner, M., \& Rubinson, L. (1993). Acquaintance rape: The influence of alcohol, fraternity membership, and sports team membership. Journal of Sex Education and Therapy, 19, 272-284.

Gaillot, M. (1999). Multiple meaning techno: An artistic and political laboratory of the present (W. Niesluchowski, Trans.). Paris: Editions Dis Voir.

Garland, G. (2001, April 16). Police arrest dozens at rave. The Baltimore Sun, p. 1B.

Gilbert, S., \& Gubar, S. (1979). The madwoman in the attic: The woman writer and the nineteenth-century literary imagination. New Haven, CT: Yale University Press.

Goldstein, L. (2001, July 15). Raves, death \& ecstasy-yesterday's news. The Toronto Sun, p. C3.

Grosz, E. (1994). Volatile bodies: Toward a corporeal feminism. Bloomington: Indiana University Press.

Hadley, D. (1993). "Ride the Rhythm:" Two approaches to dj practice. Journal of Popular Music Studies, 5, 58-67.

Hanrahan, J. (2001, May 15). Just say no. The San Diego Union-Tribune, p. E1

Haslam, D. (1997). DJ culture. In S. Redhead (Ed.), The clubcultures reader: Readings in popular culture studies (pp. 150-161). Malden, MA: Blackwell Publishers.

Hebdige, D. (1981). Subculture: The meaning of style. New York: Routledge.

Heller, S. (1998). The attack of the designer authorpreneur. AIGA Journal of Graphic Design, 16(2), 35-36.

Kellner, D. (1995). Media culture: Cultural studies, identity and politics between the modern and the postmodern. New York: Routledge.

Koss, M \& Gaines, J. (1993). The prediction of sexual aggression by alcohol use athletic participation and fraternity affiliation. Journal of Interpersonal Violence, 8, 94-108

Krashinsky J (2001, March 23). The highs and the lows. The Jerusalem Post, p. 5B.

LaGassa, L. (1996, November 18). Re: P.L.U.R. Message posted to NE-Raves electronic mailing list, archived at http://www.hyperreal.org/raves/spirit/plur/ Origin_of_PLUR.html

Langlois, T. (1992). Can you feel it? DJs and house music in the UK. Popular Music $11(2), 229-238$.

Leitch, V. (1983). Deconstructive criticism: An advanced introduction. New York: Columbia University Press.

Mattila, I. (1999, February). A dj is an artist too. Finnish Music Quarterly, pp. 56-58.

May, M. (2001, June 20). New wave of raves; Once-underground parties now marketed to the masses. The San Francisco Chronicle, p. A1. 
Melechi, A. (1993). The ecstasy of disappearance. In S. Redhead (Ed.), Rave off: Politics and deviance in contemporary youth culture (pp. 29-40). Burlington, VT: Ashgate Publishing.

Morley, D., \& Robins, K. (1989). Spaces of identity: Communication technologies and

the reconfiguration of Europe. Screen, 30, 10-34.
Morley, D., \& Robins, K. (1995). Spaces of identity: Global media, electronic landscapes and cultural boundaries. New York: Routledge.

Muehlenhard, C., \& Linton, M. (1987). Date rape and sexual aggression in dating situations: Incidence and risk factors. Journal of Counseling Psychology, 34, $186-196$.

Poschardt, U. (1998). DJ culture (S. Whiteside, Trans.). London: Quartet Books Ltd.

Reighley, K. (2000). Looking for the perfect beat: The art and culture of the dj. New York: Pocket Books.

Reynolds, S. (1997). Rave culture: Living dream or living death? In S. Redhead (Ed.), The clubcultures reader: Readings in popular cullure studies (pp. 84-93). Malden, MA: Blackwell Publishers

Reynolds, S. (1998). Generation ecstasy: Into the world of techno and rave culture. Boston: Little, Brown and Company.

Richburg, K. (2001, April 15). Pragmatic Dutch tolerate ecstasy use; Despite U.S. alarm, party drug is widely used in the Netherlands. The Washington Post, $\mathrm{p}$ A16.

Sanjek, D. (1992). "Don't have to dj no more": Sampling and the "autonomous" creator. Cardozo Arts and Entertainment Law Journal, 10, 607-624.

Saunders, N. (1996). Ecstasy: Dance, trance, and transformation. Oakland, CA: Quick American Archives.

Shuker, R. (1994). Understanding popular music. London: Routledge.

Sicko, D. (1999). Techno rebels: The rencgades of electronic funk. New York: Billboard.

Silk, M. S., \& Stern J. P. (1981). Nietzsche on tragedy. Cambridge: Cambridge University Press.

Stallybrass, P., \& White, A. (1986). The politics and poetics of transgression. Ithaca, NY: Cornell University Press.

Straw, W. (1999). Authorship. In B. Horner \& T. Swiss (Eds.), Key terms in popular music and culture (pp. 199-208). Malden, MA: Blackwell.

Thornton, S. (1996). Club cultures: Music, media and subcultural capital. London: Wesleyan University Press.

van Poecke, L. (1996). Media culture and identity formation in the light of postmodern invisible socialization: From modernity to postmodernity. Communications, 21, 183-198.

Willis, P. (1978). Profane culture. London: Routledge and Kegan Paul.

Zita, J. (1998). Body talk: Philosophical reflections on sex and gender. New York: Columbia University Press. 